\title{
European firm adjustment during times of economic crisis
}

\author{
Silvia Fabiani ${ }^{1}$, Ana Lamo ${ }^{2 *}$, Julián Messina ${ }^{3,4}$ and Tairi Rõõm ${ }^{5}$
}

\footnotetext{
* Correspondence: ana.lamo@ecb.int European Central Bank, Frankfurt, Germany

Full list of author information is available at the end of the article
}

\begin{abstract}
This paper exploits a unique cross-country, firm-level survey to study the responses of European firms to the sharp demand and credit contraction triggered by the global Great Recession of 2009. The analysis reveals that cost reduction-particularly labour cost reduction through the adjustment of quantities rather than prices - was the prevailing strategy that firms had adopted by summer 2009. Remarkably, not even during the worst postwar recession did employers cut base wages to reduce costs. Different combinations of adjustment strategies are apparent, and the particular choices of labour costs adjustments depend substantially on countries' institutional settings.
\end{abstract}

JEL codes: J30, J32, J33, J51

Keywords: Labour costs; Margins; Demand and credit shocks; Employment; Firm survey; Wage cuts; European Union

\section{Springer}

\section{Introduction}

How do firms adjust to a deep and sudden fall in demand? Are these reactions different or reinforced when the drop in sales is paired with a credit drain? A firm can adjust through prices, margins, and costs. The menu of cost-cutting alternatives is large: firms might, at least partially, pass the costs of the fall in demand along to suppliers, renegotiating the prices of intermediate inputs. In parallel, or alternatively, firms might adjust labour costs by lowering either employment or wages. The relative importance of each of these margins of adjustment is likely to depend on the intensity and nature of the shock as well as on the structural features of the product and labour markets where the firm operates. This paper sheds some new light on these questions, drawing on a large survey of European firms during the 2009 global economic crisis.

The survey, carried out by the Wage Dynamics Network (WDN), a research network of the European System of Central Banks (ESCB), was administered in two waves. The first, conducted during the last two quarters of 2007 and the first quarter of 2008, included a wide array of questions on firm characteristics, workforce composition, priceand wage-setting behaviours, and certain features of the economic environment in which the firm operated at that time. Importantly, the base period of observation predates the Great Recession, and hence information refers to each firm's structural characteristics before the negative shocks hit. The second wave, during the third quarter of

(c) 2015 Fabiani et al. Open Access This article is distributed under the terms of the Creative Commons Attribution 4.0 International License (http://creativecommons.org/licenses/by/4.0/), which permits unrestricted use, distribution, and reproduction in any medium, provided you give appropriate credit to the original author(s) and the source, provide a link to the Creative Commons license, and indicate if changes were made. 
2009, was designed to assess the adjustment mechanisms the firm was using, or planning to use, to cope with the global crisis.

The main advantage and rationale for launching an ad hoc survey of private sector firm managers during the Great Recession lay in the wealth and scope of information that could be collected. Typical firm-level data have little information on a firm's labour force, hence are silent on the different channels of labour cost adjustment. Matched employer-employee data constitute a great stride towards filling this gap, but even in this case, important information is missing. The information on the firm side is usually rather limited, constraining the analysis of the adjustment strategies that firms may use. Moreover, the nature of the shocks hitting the firms is usually not observed, and hence has to be inferred from the data. Instead, the use of a survey allows respondents to assess qualitatively the nature and intensity of these shocks.

This paper, after presenting the firms' perceptions of the shocks they faced, discusses the various adjustment mechanisms that firms put in place in response to these shocks during the incipient stages of the global economic crisis in 2008-09. First, we look at the primary responses to these negative shocks: changes in output, prices, margins, and costs. The discussion illustrates the importance of cost-cutting strategies relative to the other adjustment mechanisms and introduces the second part of the analysis, where we concentrate on the alternative cost-cutting strategies the firms adopted. In particular, we investigate the relative importance of wage reductions (in either base wages or flexible wage components), reductions in labour inputs (e.g., hours), and the adjustment of temporary and permanent workers. As a residual option, we also assess the importance of nonlabour cost-cutting policies.

The closest work to our paper is Bertola et al. (2012), who analyse the different adjustment strategies firms can employ in response to hypothetical supply-side shocks using data from the first wave of the same survey we exploit here. In this paper, rather than looking at a firm's response to a hypothetical cost shock, we concentrate on its actual response during the Great Recession's initial phase in Europe-from the start of the crisis (third quarter of 2008) through mid-2009. This period was characterised by a large negative demand shock accompanied by a credit crunch. Hence, the main difference between the two studies lies in the nature of the shock considered and in the hypothetical shock addressed in the 2007 questionnaire versus the factual shock addressed in the 2009 questionnaire.

Our findings illustrate the vast heterogeneity of firm reactions to these negative shocks. Yet they also show how the different responses were theoretically consistent-both with the firms' internal characteristics and with the features of the labour and product markets in which they operate. Some important messages stand out: base wages are cut, if at all, as a last resort. During the first year of the worst economic crisis since the Great Depression, firms were unwilling to cut base wages in an attempt to protect jobs. The only notable exception were Estonian firms, which suffered the worst negative shock and operate in the most flexible wagesetting institutional environment among our sample of countries.

Adjustment of nonlabour costs is the first cost-cutting strategy that European firms were willing to adopt, and laying off permanent workers was the last. Reduction of flexible wage components and temporary jobs serve as a buffer when other forms of adjustment are unavailable or unaffordable. 
The rest of the paper is organised as follows. The next section describes the data used in the analysis. Section 3 discusses the main theoretical channels through which firms are likely to cope with a fall in demand or a negative shock in credit markets, setting the scene for the empirical analysis of the following sections. Section 4 presents the nature of the shocks hitting the sample of European firms covered in the survey. Section 5 focuses on the broad margins of adjustment that firms use-from pricesetting mechanisms to changes in profit margins and costs. Section 6 concentrates instead on the subset of firms that adjusted costs in response to the Great Recession. The wealth of information from our surveys allows us to examine how different cost-cutting strategies relate to firm and institutional characteristics. Section 7 concludes.

\section{Data}

The analysis is based on a cross-country, firm-level dataset collected through surveys conducted by an ESCB research network, the Wage Dynamics Network. The surveys were deployed in two waves. The first wave was launched by the national central banks of 17 European countries (Austria, Belgium, Cyprus, the Czech Republic, Estonia, France, Greece, Hungary, Ireland, Italy, the Netherlands, Lithuania, Luxembourg, Poland, Portugal, Slovenia, and Spain) between the second half of 2007 and the first quarter of $2008^{1}$. Its aim was to collect information on firms' wage- and price-setting practices (most of which is not available from other sources) as well as on a wide range of the firms' characteristics. The survey samples were designed to be representative at the country level, and the questionnaires were harmonised across countries ${ }^{2}$.

The second wave of the survey went to the field between July and September of 2009. It was carried out in only 11 countries (Austria, Belgium, Cyprus, the Czech Republic, Estonia, France, Italy, the Netherlands, Luxembourg, Poland, and Spain) and submitted to firms that had participated in the first wave. This questionnaire was shorter and aimed specifically to investigate the recession's impact on the firms' adjustment margins, with particular emphasis on wage and labour strategies.

Both waves were addressed to enterprise managers and were conducted either by traditional mail, phone, face-to-face interviews, or through the Internet.

The survey's sample size, sampling probabilities, and nonresponse patterns varied across countries, as well as sectoral coverage and firm size. The analysis presented here is based on the subset of the firms that participated in both waves. We consider only firms with at least five employees in manufacturing, trade, and market services-the sectors covered in all countries. We exclude data from Cyprus and Luxembourg because they are not fully comparable in the aspects this paper focuses upon. The analysis considers a total of 4,658 firm-level observations. Table 1 shows the distribution of the final sample by country, sector, and size.

To make the results representative of the total population of the sectors considered, the cross-country statistics presented in the following sections are constructed using employment-adjusted weights that add up to total employment in the population the sample represents ${ }^{3}$.

An advantage of our data is that, in the first wave of the survey, firms were directly asked about certain features of their institutional setups and economic environments that are rarely available in administrative and household datasets. As for the firm-level institutional arrangements governing wage formation, the survey provides evidence on, 
Table 1 Sample composition by country, sector, and firm size

\begin{tabular}{lrr}
\hline & \# firms & Per cent \\
\hline Austria & 262 & 5.6 \\
Belgium & 806 & 17.3 \\
Czech Republic & 223 & 4.8 \\
Estonia & 140 & 3.0 \\
Spain & 962 & 20.6 \\
France & 818 & 17.6 \\
Italy & 668 & 14.3 \\
Netherlands & 529 & 11.4 \\
Poland & 250 & 5.4 \\
Total & 4658 & 100 \\
\hline Manufacturing & 2338 & 50.2 \\
Trade & 971 & 20.9 \\
Market Services & 1349 & 29 \\
\hline Firm size: 5-19 & 1116 & 24 \\
Firm size: $20-49$ & 1057 & 22.7 \\
Firm size: $50-199$ & 1408 & 30.2 \\
Firm size: $200+$ & 1077 & 23.1 \\
\hline Source: WDN sur & &
\end{tabular}

Source: WDN surveys

among other things, the adoption and coverage of collective agreements, the extent of firm-level adjustment of wages to inflation, whether the firm follows time-dependent or state-dependent rules to modify wages and prices, and how frequent those adjustments are. Concerning the economic environment, the aspects of greater interest for our analysis are those that directly affect wage and labour adjustment strategies, that is, the degree of competitive pressure faced by the firm, its exposure to foreign markets, and different aspects of its price-setting behaviour. Another important set of relevant data from the survey concerns the firm's workforce composition (fraction of permanent and temporary workers, of high-skilled and low-skilled workers, of white-collar and bluecollar workers); the degree of labour turnover; and the share of labour costs in total costs.

Most importantly for our analysis, information on all these features relates to the timing of the first wave of the survey, usually 2007-a period preceding the demand and financial shocks in Europe from the global crisis. This timing renders such structural features predetermined, in a purely econometric sense, relative to the responses to shocks that this paper focuses upon in the empirical analysis.

By summer 2009, when the respondents were recontacted in the second wave of the survey to answer a short questionnaire on the impact of the crisis and their reactions to it (see Additional file 1), the economic environment had changed considerably. Business activity was falling in most countries, inflation had declined substantially, unemployment rates were increasing, and the short-term outlook was highly uncertain. Firms were asked, among other things, to assess the intensity of the demand decrease for their products as well as the stringency of the financial constraints they suffered because of the crisis. The respondents who acknowledged a fall in demand were then asked to qualify the nature of their reactions to it by assessing the relative relevance of 
specific margins of adjustment: prices, margins, output, and costs. In the final part of the questionnaire, firms that considered cost reductions to be a relevant adjustment strategy to counter the fall in demand were further asked about the "most important channel through which they achieved those reductions".

The response rate for the second wave of the survey was 53\%. Because only about half of the firms that participated in the first wave also agreed to take part in the second, our sample may be potentially biased. The bias may stem from the nonrandom selection of firms in the second wave of the survey (e.g., some firms hit by a particularly strong negative shock ceased to exist). To assess the relevance of this potential selection bias, we compare the characteristics of the firms that participated in both surveys (uncensored firms) with those of the firms that responded only to the first wave (censored firms). The comparison between the mean values in the two groups for these selected characteristics (later used as explanatory variables in the regressions) shows that the censored and uncensored samples are quite similar (Table 2). In particular, we do not find a significant loss of smaller firms, which suggests that attrition (at the time of the survey) was not particularly concentrated among those firms that presumptively would have been considered more vulnerable.

\section{Theoretical considerations}

The optimal response of firms to a negative shock is broadly determined by three factors: the nature of the shock, the firm's particular situation when the shock occurs, and the firm's product and labour market environments. Of particular relevance for this paper is the interaction between (a) the structural and institutional features of the product and labour market environments and (b) the alternative cost-cutting strategies.

Table 2 Censored and uncensored firms: comparison of sample means

\begin{tabular}{lllll}
\hline & $\begin{array}{l}\text { Mean } \\
\text { (uncensored) }\end{array}$ & $\begin{array}{l}\text { Mean } \\
\text { (censored) }\end{array}$ & $\begin{array}{l}\text { Observations } \\
\text { (uncensored) }\end{array}$ & $\begin{array}{l}\text { Observations } \\
\text { (censored) }\end{array}$ \\
\hline Manufacturing & 0.502 & 0.475 & 4658 & 3972 \\
Trade & 0.208 & 0.204 & 4658 & 3972 \\
Market Services & 0.290 & 0.321 & 4658 & 3972 \\
Firm size: 5-19 & 0.240 & 0.264 & 4658 & 3972 \\
Firm size: 20-49 & 0.227 & 0.214 & 4658 & 3972 \\
Firm size: 50-199 & 0.302 & 0.292 & 4658 & 3972 \\
Firm size: > = 200 & 0.231 & 0.231 & 4658 & 3972 \\
Share of white-collar workers & 0.371 & 0.332 & 4303 & 3698 \\
Share of high-skilled workers & 0.402 & 0.429 & 4303 & 3698 \\
Share of permanent workers & 0.908 & 0.896 & 4608 & 3897 \\
Labour turnover & 0.336 & 0.338 & 4373 & 3666 \\
Labour cost share & 0.331 & 0.327 & 4265 & 3601 \\
Strong competitive pressures & 0.552 & 0.564 & 4106 & 3637 \\
Flexible pay component & 0.084 & 0.095 & 3939 & 3581 \\
Time-dependent wage change & 0.585 & 0.596 & 4600 & 3913 \\
Wage change more often than yearly & 0.137 & 0.141 & 4563 & 3891 \\
Wage change yearly & 0.654 & 0.678 & 4563 & 3891 \\
Wage change less often than yearly & 0.183 & 0.160 & 4563 & 3891 \\
\hline Source WDN suveys & & & &
\end{tabular}

Source: WDN surveys 
However, before analysing these strategies, we move one step backwards to discuss the firms' main options for reacting to a negative demand or credit shock: reductions in prices, output, margins, and costs.

The origin of the shock, its expected duration, and its depth are all relevant to the optimal choice between these options. A negative demand shock is likely to lead to both price and output cuts. The "price versus quantity" responses depend on the extent of price and wage stickiness the firm faces and on its degree of market power. If prices are flexible, the reaction to a negative demand shock largely depends on the cyclical behaviour of price and cost margins, a subject which has been of strong controversy in macroeconomics. Countercyclical markups in oligopolistic industries suggest that firms are more likely to increase margins when demand is low, hence limiting the output and price responses to shocks (Rotemberg and Saloner 1986). However, procyclical markups may also arise in noncompetitive settings (Green and Porter 1984). Procyclical markups are also a key feature of the earlier Keynesian models, where wage stickiness is the central assumption (e.g., Keynes 1936; Phelps 1968; Taylor 1980). In this setting, margins are likely to shrink in response to the negative demand shock because firms are more likely to cut prices.

If prices are sticky, margin and output cuts are more likely to occur in response to a negative demand shock. However, this response is not independent of product and labour market conditions. While the extent of output cuts in the presence of sticky prices depends mostly on the elasticity of demand, the extent of margin adjustments is influenced by the firm's monopsonistic market power and the firms' ability to cut costs, which in turn depends on the structural features of the labour markets that are discussed below.

The recent global economic crisis hit firms not only with a negative demand shock but also with an unprecedented credit crunch due to lack of confidence in the banks' balance sheets. Binding credit constraints in principle exacerbate cost-cutting strategies, but the effects on price and output channels are ambiguous. Profit-maximising firms are unlikely to cut either prices or production in response to a sudden drop in external financial resources that they perceive as temporary. Instead, firms facing a credit drain are more likely to exert pressure on internal and external costs to limit the negative impact of reduced cash flows. The specific cost-cutting channels depend on the intensity and perceived duration of the shock as well as on product and labour demand constraints.

Strategies to reduce labour costs include wage reductions (of baseline or flexible wage components) and employment adjustment (either on the intensive margin through hours worked or on the extensive margin through the number of temporary or permanent workers). This choice is affected by the nature of product market competition and the institutional constraints on wage and employment adjustment (especially, among the constraints, the interaction between union behaviour and the strictness of employment protection legislation).

Wage bargaining in most European countries occurs between workers' and employers' associations, often at higher levels of centralisation than the firm level (such as the sector and the region level). Differences in the extent of unionisation and in the level of bargaining across countries are apparent, especially between the euro area and the non-euro area countries. Similarly, there is heterogeneity within countries in the 
coverage and level of wage negotiations, which we will discuss further in the empirical analysis.

In this light, it is natural to think about labour cost reduction mechanisms in the framework of wage-bargaining models. In a "right to manage" approach, firms are always on their labour demand curve. In this setting, wage and employment responses are expected to increase with the elasticity of labour demand and (by the "Hicks-Marshall" rules of derived demand) with the price elasticity of demand in the product market. Hence, firms operating in more competitive sectors or markets are expected to show stronger quantity and price adjustments in labour. The composition of the wage bill is also important: firms with a larger share of flexible pay components in total pay are more likely to cut bonuses and less likely to cut base wages when a negative demand shock occurs.

However, wage rigidity might arise when employers and unions bargain over employment and wages. In this setting, the outcome of the bargaining game is outside the labour demand curve; in the particular case of isoelastic demand, efficient bargaining contracts imply rigid real wages (McDonald and Solow 1981). In the presence of implicit contracts, the perceived nature of the shock is also relevant. If the shock is temporary, firms are less likely to cut wages than if they perceive the shock as permanent (Guiso et al. 2005). If unionisation or implicit contracts limit the adjustment of wages to demand fluctuations, we expect to see greater adjustment of employment or hours.

Employment adjustment costs also result in allocations outside the firm's labour demand curve (Bertola 1999). Other things equal, firing and hiring costs are likely to push adjustment away from open-ended contracts and towards wages and other forms of flexible employment. However, they may also limit wage adjustments; Holden (2004) argues that unionisation and firing costs increase workers' bargaining power when contracts can only be renegotiated by mutual consent, thus increasing downward nominal wage rigidity. Consistent with this prediction, Holden and Wulfsberg (2008) find that industry data from countries with strict EPL and high union density show large downward nominal wage rigidity.

Finally, the interaction of the institutional framework governing labour markets and credit constraints is also likely to affect the choice among cost-cutting strategies. Particularly in environments with high employment protection, firms subject to credit constraints make higher use of fixed-term contracts, which carry the bulk of employment adjustment (Caggese and Cuñat 2008). Hence, firms operating in countries with morestringent EPL and having trouble financing their operations are less likely to lay off permanent workers, and they are more likely to either reduce wages or cut labour costs in alternative, more flexible ways.

\section{Incidence of financial and demand shocks during the crisis}

How intense were the negative demand and financial shocks that hit European firms in mid-2009? Were they significantly heterogeneous across countries? Did their severity depend on firms' characteristics?

Table 3 presents the shares of firms-across countries, sectors, and firm size-which reported (a) a weak demand shock, (b) a strong demand shock but a weak credit shock, and (c) both a strong demand shock and a strong credit shock. The survey question allowed answers on a scale of 1 to 4 , increasing with the intensity of each shock: (1) "None at all/marginal," (2) "Moderate," (3) "Strong," and (4) "Exceptionally strong." We group 
Table 3 Incidence of demand and credit shocks (percentages)

\begin{tabular}{|c|c|c|c|}
\hline & $\begin{array}{l}\text { Weak demand } \\
\text { shock }\end{array}$ & $\begin{array}{l}\text { Strong demand + weak } \\
\text { credit shock }\end{array}$ & $\begin{array}{l}\text { Strong demand + strong } \\
\text { credit shock }\end{array}$ \\
\hline Austria & 70.5 & 24.0 & 5.4 \\
\hline Belgium & 56.4 & 29.9 & 13.8 \\
\hline Czech Republic & 46.6 & 34.6 & 18.8 \\
\hline Estonia & 19.4 & 46.2 & 34.4 \\
\hline France & 64.4 & 30.1 & 5.6 \\
\hline Italy & 56.1 & 31.3 & 12.6 \\
\hline Netherlands & 61.7 & 27.3 & 10.9 \\
\hline Poland & 77.9 & 14.3 & 7.9 \\
\hline Spain & 59.5 & 21.0 & 19.4 \\
\hline Total & 61.6 & 26.6 & 11.9 \\
\hline Euro area & 59.9 & 28.2 & 11.9 \\
\hline Non-euro area & 67.3 & 20.9 & 11.7 \\
\hline Manufacturing & 49.6 & 34.3 & 16.1 \\
\hline Trade & 69.3 & 20.3 & 10.5 \\
\hline Market Services & 73.1 & 19.9 & 7.0 \\
\hline Firm size: 5-19 & 65.0 & 19.4 & 15.7 \\
\hline Firm size: 20-49 & 54.9 & 31.4 & 13.7 \\
\hline Firm size: 50-199 & 64.1 & 25.3 & 10.6 \\
\hline Firm size: $>=200$ & 62.6 & 27.1 & 10.3 \\
\hline
\end{tabular}

Source: WDN surveys. Note: Figures are employment-weighted and rescaled excluding "do not know" answers

answers in the latter two categories as a "strong shock" and those in the first two as "weak shock."

Some interesting facts emerge from this table:

- In mid-2009, firms in all countries perceived the negative demand shock to be more important than the credit supply shock. However, the incidence of strong negative demand shock was larger in the euro area countries (about $40 \%$ of firms) than in noneuro area countries (about 32\%).

- The euro area and non-euro area countries showed no major differences in the percentage of firms suffering both a strong demand shock and strong financial constraints (about 12\%).

- Cross-country heterogeneity is greater in terms of demand shock strength: Estonian firms reported the most severe demand shock (around 80\%), and Polish firms, the weakest (only slightly more than $20 \%$ ).

- At the sectoral level, both shocks fell disproportionally strongly on manufacturing firms.

- As expected, financial constraints were stronger among smaller firms: about $16 \%$ of the firms with 5-19 employees suffered both a negative demand shock and credit constraints, but this percentage fell to $10 \%$ among firms with more than 50 employees.

We also performed a multivariate analysis to identify the main features differentiating companies by the type and intensity of the shocks they experienced, taking into account the interaction between country, sector, and corporate characteristics. The 
approach we adopted is a multinomial logit estimation where the dependent variable, constructed on the basis of the three shock-type categories described above, assumes values from 1 to 3 . The covariates included in the estimated equation are firm-level features such as workforce composition (shares of white-collar, high-skilled, and permanent workers among total employees); fixed effects for the sector of activity; the firm's size; and the country. Information on these aspects is based on responses to the 2007 questionnaire.

The estimated coefficients for the second and third categories versus the first one (i.e., the group that reported no significant shock, which is the baseline) are presented in Table 4. The results indicate that, controlling for the country and the sector of activity, the nature and intensity of the shocks are strongly related to workforce composition. In particular, companies employing higher shares of white-collar, high-skilled, and permanent workers were less likely to experience a strong contraction of demand and credit. Another significant aspect is the degree of competitive pressure: firms with a higher exposure to foreign markets (captured by the share of turnover generated abroad) were more likely to experience both strong demand and strong credit shocks.

Clearly, a firm's perception of the demand or credit shock intensity depends on the past volatility of the underlying variable, and this may differ systematically across the sampled countries. Thus, the incidence of strong demand or credit shocks may not be

Table 4 Multinomial logit regression on the intensity of shocks (base outcome shock =1: weak demand shock)

\begin{tabular}{|c|c|c|c|c|c|}
\hline \multicolumn{3}{|c|}{ shock =2: strong demand + weak credit } & \multicolumn{3}{|c|}{ shock = 3: strong demand + strong credit } \\
\hline & coeff & tstat & & coeff & tstat \\
\hline Manufacturing & 0.5 & 4.5 & Manufacturing & 0.7 & 4.7 \\
\hline Trade & -0.1 & -0.7 & Trade & -0.2 & -1.1 \\
\hline Market Services & - & - & Market Services & - & - \\
\hline Size $5-19$ & -0.1 & -0.7 & Size $5-19$ & 0.4 & 2.4 \\
\hline Size $20-49$ & -0.1 & -0.4 & Size $20-49$ & 0.0 & 0.1 \\
\hline Size $50-199$ & -0.2 & -2.1 & Size $50-199$ & -0.3 & -2.1 \\
\hline Size $>=200$ & - & - & Size $>=200$ & - & - \\
\hline Austria & -0.4 & -1.7 & Austria & -1.4 & -3.6 \\
\hline Belgium & 0.1 & 0.8 & Belgium & -0.5 & -1.5 \\
\hline Czech_Rep & 0.1 & 0.4 & Czech_Rep & 0.1 & 0.3 \\
\hline Estonia & 1.4 & 4.4 & Estonia & 2.0 & 6.0 \\
\hline France & 0.1 & 0.6 & France & -0.7 & -3.1 \\
\hline Italy & 0.2 & 1.1 & Italy & -0.1 & -0.4 \\
\hline Netherlands & -0.2 & -1.0 & Netherlands & -0.9 & -3.5 \\
\hline Poland & - & - & Poland & - & - \\
\hline Spain & -0.3 & -1.8 & Spain & 0.1 & 0.3 \\
\hline Share of white-collar workers & -0.3 & -1.9 & Share of white collar workers & -0.5 & -2.1 \\
\hline Share of high-skill workers & -0.1 & -0.7 & Share of high-skill workers & -0.4 & -2.2 \\
\hline Share of permanent workers & -0.7 & -3.4 & Share of permanent workers & -1.1 & -4.6 \\
\hline Labour cost share & -0.7 & -2.9 & Labour cost share & -0.7 & -2.5 \\
\hline Price taker & 0.2 & 1.9 & Price taker & 0.1 & 1.2 \\
\hline Export share & 0.8 & 5.7 & Export share & 0.4 & 2.2 \\
\hline
\end{tabular}

Source: WDN surveys. Note: T-statistics are obtained from robust standard errors 
directly comparable across countries. To assess possible dissonance in the data from differences in past economic experiences, we compare the observed pattern of aggregate gross domestic product (GDP) with the average magnitude of the negative credit and demand shocks perceived by firms in each economy. Figures 1 and 2 show scatterplot diagrams depicting the cumulative change in GDP from Q2 2008 to Q2 2009 (in percentage terms) on the $y$-axes and the fraction of firms reporting either a strong demand shock (Fig. 1) or a strong credit shock (Fig. 2) on the x-axes.

The correlation coefficients are rather high in absolute terms: -0.92 and -0.81 for demand and credit shocks, respectively. When Estonia, which is the country experiencing the largest GDP contraction is excluded, the coefficients drop to -0.70 and $-0.43^{4}$. The actual change in GDP is hence sufficiently strongly correlated with the magnitude of the negative shocks perceived by firms. This correlation, however, does not rule out the possibility of a divergent interpretation of the same questions across countries or sectors. It is for this reason that the econometric exercises we carry out in the next section include country and sector fixed effects, which should control for systematic differences in historical volatility of demand and credit constraints as well as for possible differences in the interpretation of some questions.

\section{Primary reactions to shocks}

As discussed in Section 3, firms may react to a negative demand shock by adjusting prices, output, margins, and costs. This section describes how firms used each of these channels of adjustment during the 2008-09 crisis and how these patterns differed across countries and various types of firms.

This part of the questionnaire asked firms how relevant each adjustment strategy was, on a scale from 1 to 4: (1) "Not relevant," (2) "Of little relevance," (3) "Relevant," and (4) "Very relevant." To simplify the exposition, we group answers in the latter two categories as "Relevant."

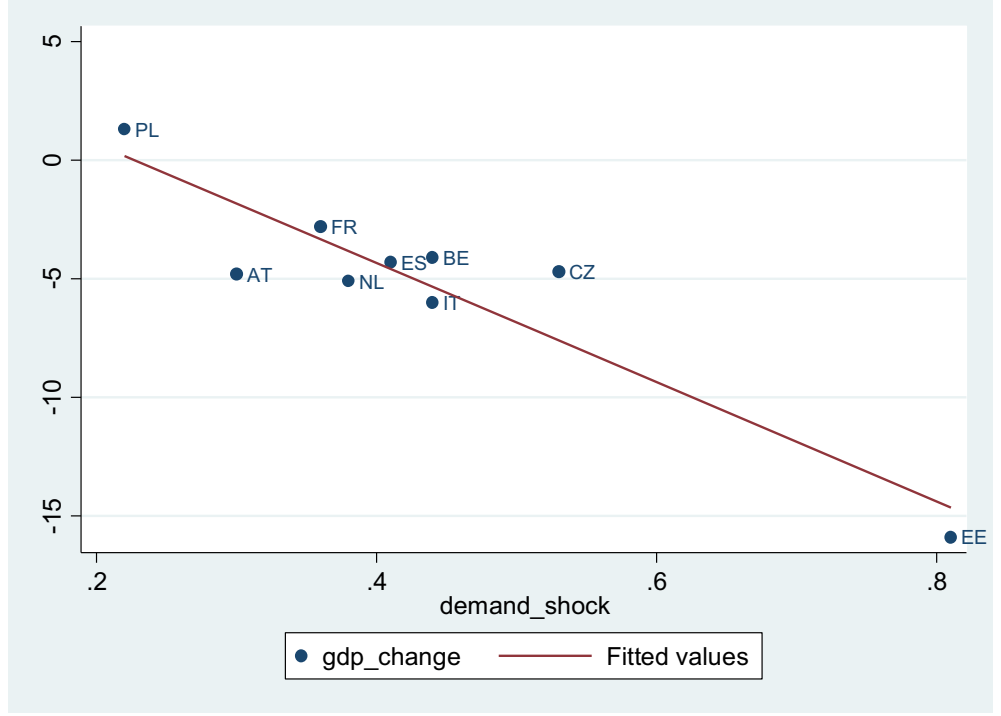

Fig. 1 GDP change vs. incidence of strong negative demand shock 


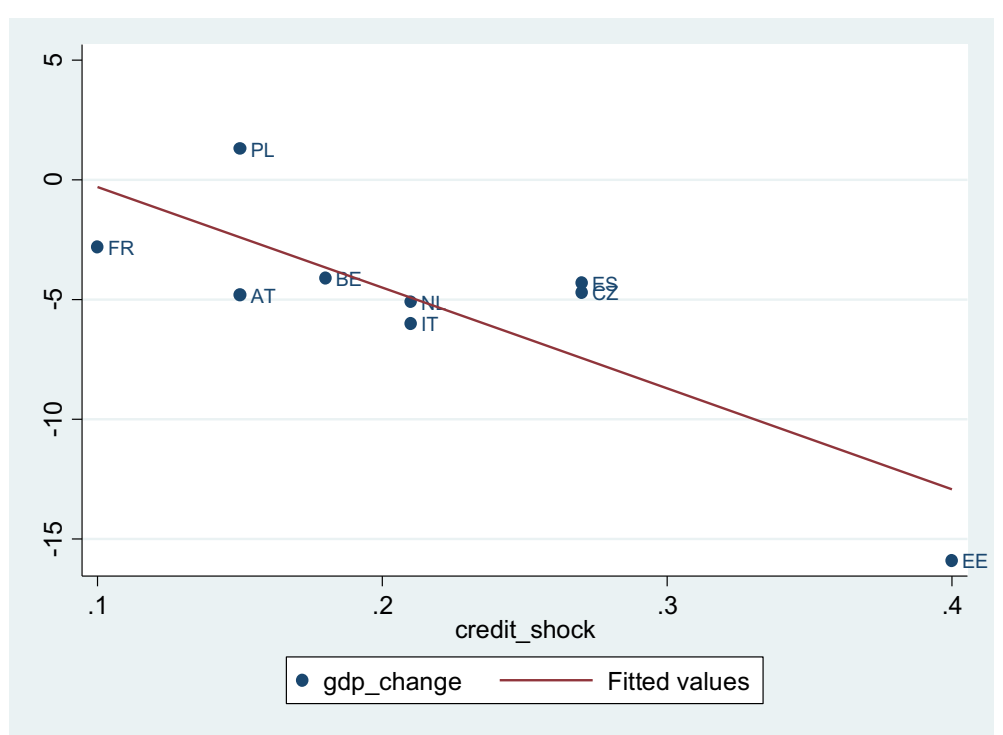

Fig. 2 GDP change vs. incidence of strong negative credit shock

Cost reduction was the most common adjustment strategy (Table 5), followed by cuts in output and margins. Interestingly, $66 \%$ of the firms that were hit by a weak demand shock responded by reducing costs. Taken at face value, this high percentage suggests that a great majority of firms are not cost-minimising ones, i.e., they have scope for further cost reductions in response to a negative demand shock ${ }^{5}$.

Not surprisingly, the fraction of firms choosing each of the proposed strategies increases with the intensity of the shock. However, this pattern is not homogeneous across strategies. In particular, reducing output is the option with the highest elasticity to the strength of the demand shock: the shares of firms choosing that option when faced with a weak or a strong demand shock were 21.3 and $62 \%$, respectively. The share rises to $67 \%$ when strong credit constraints accompany the demand shock.

In line with the theoretical predictions, the strategies most commonly followed by firms affected by credit constraints during the crisis are reductions in output, margins, and costs. Cutting margins is the main adjustment channel for $46.2 \%$ of the firms facing a strong demand and a weak credit shock; the percentage increases by 16 percentage points among the firms that also suffer strong credit constraints. Similarly, a strong credit shock increases the percentage of firms cutting costs by 16 percentage points relative to those hit only by a fall in demand. Tables 4 and 5 shows that these patterns are broadly consistent across sectors. Overall, margin and cost cuts are more relevant in the trade sector, possibly suggesting higher rents, whereas output reductions are more prevalent in manufacturing than in the other sectors, against both weak and strong demand shocks.

Firms facing more severe negative shocks used all possible channels of adjustment more intensively. Indeed, the pair-wise correlations (Table 6) show that the incidence of the various strategies (particularly of price and margin reductions) is positively correlated.

Table 7 presents the proportion of firms that considered various combinations of adjustment channels to be "relevant" or "very relevant." We sort these combinations on the basis of their incidence in the overall sample of firms. In addition, the last row presents the proportion of firms that considered none of the four channels 
Table 5 Firms' reactions to shocks, by sector (percentage of firms attributing relevance or great relevance to a given reaction)

\begin{tabular}{|c|c|c|c|}
\hline & Weak demand & Strong demand + weak credit shock & Strong demand + strong credit shock \\
\hline \multicolumn{4}{|l|}{ All sectors } \\
\hline Reduce prices & 31.5 & 41.7 & 50.3 \\
\hline Reduce margins & 37.0 & 46.2 & 62.2 \\
\hline Reduce output & 21.3 & 61.9 & 66.8 \\
\hline Reduce costs & 66.5 & 77.8 & 93.8 \\
\hline \multicolumn{4}{|l|}{ Manufacturing } \\
\hline Reduce prices & 34.6 & 37.4 & 48.1 \\
\hline Reduce margins & 38.7 & 44.5 & 63.7 \\
\hline Reduce output & 36.1 & 74.6 & 76.8 \\
\hline Reduce costs & 68.0 & 77.1 & 95.3 \\
\hline \multicolumn{4}{|l|}{ Trade } \\
\hline Reduce prices & 37.1 & 48.1 & 60.4 \\
\hline Reduce margins & 46.5 & 55.4 & 75.2 \\
\hline Reduce output & 15.6 & 34.6 & 43.7 \\
\hline Reduce costs & 78.4 & 86.6 & 96.1 \\
\hline \multicolumn{4}{|l|}{ Market Services } \\
\hline Reduce prices & 25.6 & 48.1 & 50.9 \\
\hline Reduce margins & 30.9 & 45.3 & 54.1 \\
\hline Reduce output & 10.8 & 47.4 & 51.4 \\
\hline Reduce costs & 58.7 & 74.1 & 86.8 \\
\hline
\end{tabular}

Source: WDN surveys. Note: Figures are employment-weighted and rescaled excluding "do not know" answers

to be "relevant" or "very relevant". Interestingly, all of the relevant combinations include cost reduction.

Among firms experiencing a strong demand shock, as expected from theoretical predictions, the most relevant adjustment mechanism was cost reduction in combination with output reduction,. Among those experiencing only a weak demand shock, the most relevant option was cost cutting in isolation. However, companies suffering strong shocks on both the demand and financial sides responded that all possible adjustment channels were relevant: reduction in output, margins, prices, and costs.

\section{Alternative cost-cutting strategies}

\subsection{Descriptive evidence}

The remainder of the paper focuses on cost-cutting strategies, discussing in greater depth the various alternatives that firms implemented during the crisis. The 2009 survey

Table 6 Adjustment strategies: pair-wise correlations

\begin{tabular}{lllll}
\hline Adjustment strategy & Price & Margin & Output & Cost \\
\hline Price & 1 & & & \\
Margin & 0.74 & 1 & 1 & \\
Output & 0.29 & 0.35 & 0.42 & 1 \\
Cost & 0.31 & 0.34 &
\end{tabular}

Source: WDN surveys. Note: Figures are employment-weighted 
Table 7 Relevance of varied combinations of adjustment strategies to firms, by type and severity of shock (percentage)

\begin{tabular}{|c|c|c|c|c|c|c|c|}
\hline $\begin{array}{l}\text { Reduce } \\
\text { price }\end{array}$ & $\begin{array}{l}\text { Reduce } \\
\text { margins }\end{array}$ & $\begin{array}{l}\text { Reduce } \\
\text { output }\end{array}$ & $\begin{array}{l}\text { Reduce } \\
\text { costs }\end{array}$ & All firms & $\begin{array}{l}\text { Weak demand } \\
\text { shock }\end{array}$ & $\begin{array}{l}\text { Strong demand + } \\
\text { weak credit shock }\end{array}$ & $\begin{array}{l}\text { Strong demand }+ \\
\text { strong credit shock }\end{array}$ \\
\hline & & $\bullet$ & $\bullet$ & 15.9 & 9.4 & 26.9 & 22.6 \\
\hline & & & $\bullet$ & 15.6 & 20.3 & 8.8 & 8.2 \\
\hline$\bullet$ & $\bullet$ & $\bullet$ & $\bullet$ & 13.9 & 9.7 & 18.1 & 28.3 \\
\hline \multirow[t]{2}{*}{$\bullet$} & $\bullet$ & & $\bullet$ & 10.8 & 11.1 & 10.4 & 8.9 \\
\hline & $\bullet$ & $\bullet$ & $\bullet$ & 5.8 & 2.9 & 7.9 & 18.5 \\
\hline$x$ & $x$ & $x$ & $x$ & 21.1 & 29.9 & 8.9 & 1.9 \\
\hline
\end{tabular}

Source: WDN surveys. Note: Each of the top five rows shows the proportion of firms responding that a given "combination" of adjustment channels is either "relevant" or "very relevant" to its crisis response. The bottom row designates the proportion of firms responding that none of the four channels is relevant. Figures are employment-weighted and rescaled excluding "do not know" answers

distinguishes among the following six cost-cutting routes: base wages, flexible wage components; working hours, layoffs of permanent or temporary employees; and nonlabour costs. Managers were asked to single out the option they consider to be "the most important."

Overall, labour costs were adjusted more widely than nonlabour costs in response to the crisis (Table 8): on average, for $64 \%$ of the surveyed firms, the main strategy was some type of labour cost reduction (ranging from $77 \%$ in Estonia and Spain to 51\% in Poland). The percentage jumps to $77 \%$ among firms that faced a strong demand shock in conjunction with a weak credit shock, and it is slightly higher (79\%) among those confronted with both strong demand and credit shocks.

Considering each option in isolation, however, firms cut nonlabour costs more often than any single form of labour costs. Our survey is silent on the precise nature of the nonlabour cost reductions, but the potential set of alternatives is ample, depending also on the firm's sector and degree of vertical integration. For example, price renegotiation with providers is one common strategy during crises; another is downsizing of ancillary activities (which might be considered nonessential), typically through externalisation.

Interestingly, according to our survey, nonlabour cost reductions were much more common among firms that faced weak demand and credit reductions (almost 43\%) than among those that suffered strong shocks on both ends (about 21\%). This finding suggests a notable pattern in firms' responses to a fall in demand: nonlabour costs are the first to be cut. Firms reduce labour costs only when the shock is either relatively intense or expected to be long-lasting. Unfortunately, our questionnaire does not allow us to disentangle these two hypotheses.

Among the channels of labour cost reduction, almost none of the firms chose base wages as the "most important" option (only 1.2\% overall, ranging from $0 \%$ in the Czech Republic to $14 \%$ in Estonia). This result confirms that, even during the most severe global financial crisis of post-World War II history, a high degree of downward nominal wage rigidity persisted-deviating little from firms' usual practice during nonrecessionary periods, based on past survey evidence from developed nations such as Switzerland and the United States ${ }^{7}$.

To some extent, the lack of flexibility in base wages might be offset by adjusting nonbase wage components, although the same forces that impose rigidity in the former might also limit changes in bonuses and fringe benefits. The empirical analysis will further investigate this issue, but the summary statistics shown in Table 8 indicate that 
Table 8 Firms' cost-cutting strategies in response to economic shocks (percentage of firms choosing a given strategy as the "most important factor" in cost reduction)

\begin{tabular}{lcccccc}
\hline & $\begin{array}{c}\text { Base } \\
\text { wages }\end{array}$ & $\begin{array}{c}\text { Flexible } \\
\text { wages }\end{array}$ & $\begin{array}{c}\text { Permanent } \\
\text { employment }\end{array}$ & $\begin{array}{c}\text { Temporary } \\
\text { employment }\end{array}$ & $\begin{array}{c}\text { Hours } \\
\text { worked }\end{array}$ & $\begin{array}{c}\text { Nonlabour } \\
\text { costs }\end{array}$ \\
\hline By country & 0.3 & 12.2 & 12.2 & 11.1 & 36.2 & 28.0 \\
Austria & 0.9 & 3.1 & 16.8 & 29.6 & 24.9 & 24.6 \\
Belgium & 0.0 & 10.4 & 27.9 & 16.4 & 5.3 & 40.1 \\
Czech Republic & 14.3 & 25.1 & 24.2 & 3.7 & 9.3 & 23.5 \\
Estonia & 0.1 & 9.9 & 17.1 & 33.9 & 12.4 & 26.2 \\
France & 1.3 & 8.9 & 16.6 & 21.1 & 18.4 & 33.7 \\
Italy & 1.4 & 5.0 & 8.1 & 40.5 & 6.2 & 38.8 \\
Netherlands & 1.9 & 15.9 & 16.7 & 9.1 & 7.6 & 48.7 \\
Poland & 1.0 & 5.5 & 23.2 & 41.6 & 5.9 & 22.8 \\
Spain & 1.2 & 9.8 & 16.9 & 24.3 & 13.6 & 33.9 \\
Total & & & & & & \\
By type of shock & 0.8 & 9.5 & 13.2 & 21.6 & 11.6 & 42.5 \\
Demand (weak) & 1.6 & 11.9 & 17.5 & 29.8 & 16.1 & 22.6 \\
Demand (strong) + credit (weak) & 2.4 & 7.0 & 31.2 & 24.0 & 14.6 & 20.8 \\
Demand + credit (both strong) & 2.9 &
\end{tabular}

Source: WDN surveys. Note: The table presents percentages of firms; they are employment-weighted and rescaled excluding "do not know" answers

flexible wage components indeed represent an important margin of adjustment for our sample of European firms: almost $10 \%$ chose it as the "most important" cost-cutting option during the recent economic crisis. The percentage was higher in non-euro area countries, especially Estonia (25\%) and Poland (16\%).

Among the three top labour cost reduction strategies overall-laying off permanent employees, laying off temporary employees, or reducing hours worked-the latter was the least common option. However, countries show wide heterogeneity in this regard: Austrian firms were the most widely resolved to reduce working hours to accommodate the fall in demand during the crisis (36\% of which said this margin was the "most important" cost-cutting strategy). At the other extreme, only 5-6\% of the Spanish and Czech firms singled out that option. The high incidence in Austria is likely related to Kurzarbeit (or "short work"), a temporary institutional arrangement which allows employers to reduce working hours and pays employees government-subsidised special allowances instead of regular wages to cover most of the earnings shortfall. Employees must agree to the hour reductions, which can vary widely, ranging between 10 and $90 \%$ of regular work time. Although the Kurzarbeit period in Austria typically could not exceed six months, the Austrian government, in light of the ongoing recession, changed the rules in early 2009 to allow up to 18 months of Kurzarbeit in extreme cases.

Overall, the most widely adopted means of cutting labour costs has been to lay off temporary employees. Spain (the country in the sample with the highest incidence of temporary-employee contracts) and the Netherlands stand out in this respect: almost $42 \%$ of the firms in Spain and $40 \%$ in the Netherlands tagged it as the "most important" option. At the other extreme, 24.2\% of Estonian companies said reducing permanent jobs was "most important" as opposed to $3.7 \%$ which would opt to cut temporary jobs. 
Interestingly, the share of firms choosing layoffs of permanent employees as the "most important" strategy increases monotonically with the intensity of the shocks. Among the firms that had faced a weak negative demand shock by summer 2009, only $13 \%$ chose permanent employment as the "most important" cost to cut; among the firms that faced a strong demand shock but a weak credit-constraint shock, that percentage increases to $18 \%$. The percentage almost doubles (to $31 \%$ ) among firms that faced both a strong credit and strong demand shocks. These results suggest that only when shocks become large are employers willing to start cutting open-ended contract jobs.

Section 3 discussed the prominent role of the labour market institutional setting in shaping the optimal firm response to a negative demand shock. Indeed, although the patterns outlined above are broadly consistent across sectors, firms show significant heterogeneity by country in their behaviour. In particular, two institutional features, union bargaining power and the stringency of employment protection legislation (EPL), are likely to have major impacts on the cost-cutting strategies analysed here.

According to indicators based on our surveys and to the index of EPL severity in 2008 constructed by the Organisation of Economic Co-operation and Development (OECD), non-euro area countries tend to have far less collective bargaining coverage than euro area countries, whereas EPL differences between the two groups are not as marked (Table 9).

Consistent with the theoretical predictions, in countries where firing costs are higher, larger percentages of firms lay off temporary employees instead of employees with open-ended contracts (Fig. 3). The slope of the regression line is 0.24 and significant at the 5\% level (right chart). However, there is no evidence of the inverse relationship regarding permanent workers: the correlation coefficient between the percentage of firms that implemented permanent job cuts and EPL is not statistically different from zero (left chart).

As for the relationship between collective bargaining coverage and "quantity versus price" labour market adjustments, higher union coverage appears to be inversely related to firms' ability to adjust wages (Fig. 4) - either base wages (top left) or flexible wage components (top right). Only in the latter case, however, is the regression slope statistically different from zero (coefficient 0.155, standard error 0.054).

The graphs in the bottom row of Fig. 4 suggest that this inability of firms to use wages as an adjustment mechanism is compensated by somewhat more frequent employment reductions. In countries with high union coverage, companies cut temporary employment (bottom left) and hours (bottom right) more often. However, only in the former case is the relationship with union coverage statistically significant (coefficient 0.232, standard error 0.109).

\subsection{Wage cuts and freezes}

The survey yielded this striking result: virtually no firm considered base wage cuts to be its primary strategy for reducing costs until mid- $2009^{8}$. However, this evidence is not sufficient to infer that base wage cuts did not occur during the crisis, since the survey asked for each firm's single "most important" cost-cutting strategy. However, the depth of the recession in 2009-which, in several countries, was also coupled with 
Table 9 Collective bargaining and EPL strictness

\begin{tabular}{lccccc}
\hline & $\begin{array}{l}\text { Collective } \\
\text { bargaining } \\
\text { coverage } \\
\text { (\%, employees) }\end{array}$ & $\begin{array}{l}\text { Bargaining } \\
\text { agreements, } \\
\text { any level } \\
(\%, \text { firms) }\end{array}$ & $\begin{array}{l}\text { Bargaining } \\
\text { agreements, } \\
\text { higher-level } \\
(\%, \text { firms) }\end{array}$ & $\begin{array}{l}\text { Bargaining } \\
\text { agreements, } \\
\text { firm-level } \\
(\%, \text { firms) }\end{array}$ & $\begin{array}{l}\text { OECD EPL strictness } \\
\text { indicator }^{\mathrm{a}}\end{array}$ \\
\hline Austria & 97.6 & 98.6 & 98.1 & 31.1 & 2.2 \\
Belgium & 89.0 & 99.3 & 97.9 & 33.2 & 2.5 \\
Czech Republic & 54.3 & 57.8 & 18.5 & 55.5 & 2.0 \\
Estonia & 11.7 & 14.1 & 5.6 & 11.2 & 2.3 \\
France & 67.4 & 99.9 & 97.8 & 57.6 & 2.9 \\
Italy & 97.3 & 99.7 & 99.6 & 42.5 & 2.4 \\
Netherlands & 65.1 & 74.3 & 47.4 & 26.8 & 2.1 \\
Poland & 18.1 & 21.3 & 4.0 & 19.5 & 2.2 \\
Spain & 96.9 & 100.0 & 85.8 & 14.2 & 3.0 \\
Total & 65.1 & 74.3 & 47.4 & 26.8 & 2.1 \\
Euro area & 86.4 & 96.4 & 90.1 & 37.3 & 2.6 \\
Non-euro area & 25.8 & 29.1 & 7.2 & 27.1 & 2.1 \\
\hline
\end{tabular}

Sources: WDN surveys and OECD 2008. Note: OECD = Organisation for Economic Co-operation and Development. $\mathrm{EPL}=$ employment protection legislation. The table shows the share of employees in each country covered by collective bargaining (column 1) and the percentages of firms that apply collective bargaining contracts (columns $2-4)$; the figures are employment-weighted. a. The OECD scores countries annually on a scale of least (0) to most (6) regulatory strictness concerning the temporary contracts and worker protections from dismissal

negative rates of inflation-provides an excellent laboratory to reevaluate the firms' resistance to decreasing individual wages. For this purpose, a separate question in the 2009 survey asked firms about the occurrence and coverage among employees of base wage cuts and freezes since the crisis began. It is interesting to compare the responses with those provided to the analogous question in the 2007 survey, which concerned the frequency of base wage cuts and freezes during the previous five years, hence a period of sustained growth (Table 10).

Interestingly, the incidence of wage reductions evidently did not increase much during the global economic downturn. On average, approximately $1.8 \%$ of employees in the sampled countries experienced wage cuts during the 2009 crisis, whereas this share averaged about $1 \%$ in the 2007 survey. In sharp contrast, the share of employees experiencing wage freezes rose dramatically, from $5.2 \%$ in 2007 to $31.9 \%$ in 2009 ; the jump was particularly significant in France (77.2 percentage points), the Czech Republic (37.1), and Italy (29.6).

In other words, in 2009 the degree of downward wage rigidity was still very high in Europe: firms resorted to freezing wages instead of cutting them, even in an environment of sharp economic downturn accompanied by near-zero or negative inflation.

There is one notable exception: Estonia. Approximately 44\% of Estonian firms had cut wages by summer 2009, and 39\% still planned to do so in relation to the crisis. Why is Estonia so different from the other countries examined in this work? A plausible answer lies in a combination of four factors: first, the economy has very flexible wage-setting institutions, with the lowest coverage of collective wage agreements among the sampled countries. Second, it reformed its labour regulations in 2009, imposing more flexible EPL and considerably lowering the layoff costs for employers ${ }^{9}$. As argued earlier, both factors tend to favour downward wage flexibility (see also Babecký et al. 2010). Third, Estonia in 2009 was not yet a euro area member state and had a currency board arrangement; this 

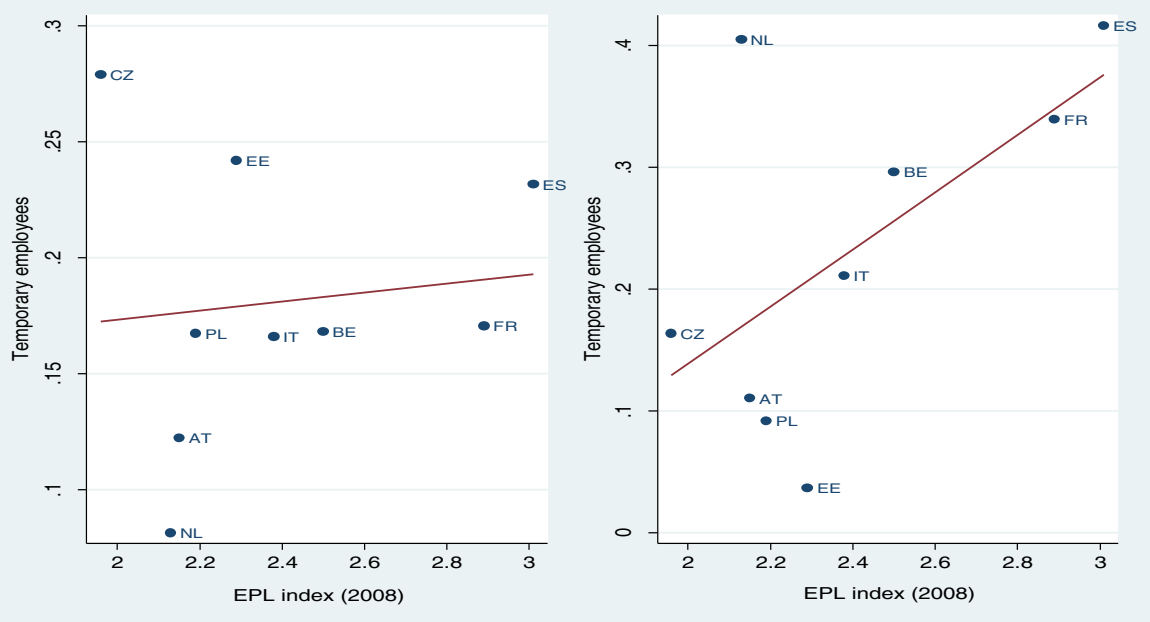

Fig. 3 Correlation of EPL strictness and firms' chosen labour cost-cutting strategy

differentiates it from the other two non-euro area countries in the sample that also have relatively flexible wage-setting systems but featured floating exchange rate regimes at the time: the Czech Republic and Poland. These two countries' national currencies depreciated during the crisis, which gave firms more leeway to optimise costs and reduced the need to cut wages. Fourth and perhaps most important, is the intensity of the negative demand shock that hit the Estonian economy: between Q2 2008 and Q2 2009, GDP fell by 16\% (in seasonally adjusted terms). Seemingly, a decline of such magnitude empowers firms to use all possible channels for cutting costs, including base wage reductions. The extent of downward flexibility in nominal base wages during the most acute phase of the crisis in Estonia has also been documented by Dabušinskas and Rõõm (2011).

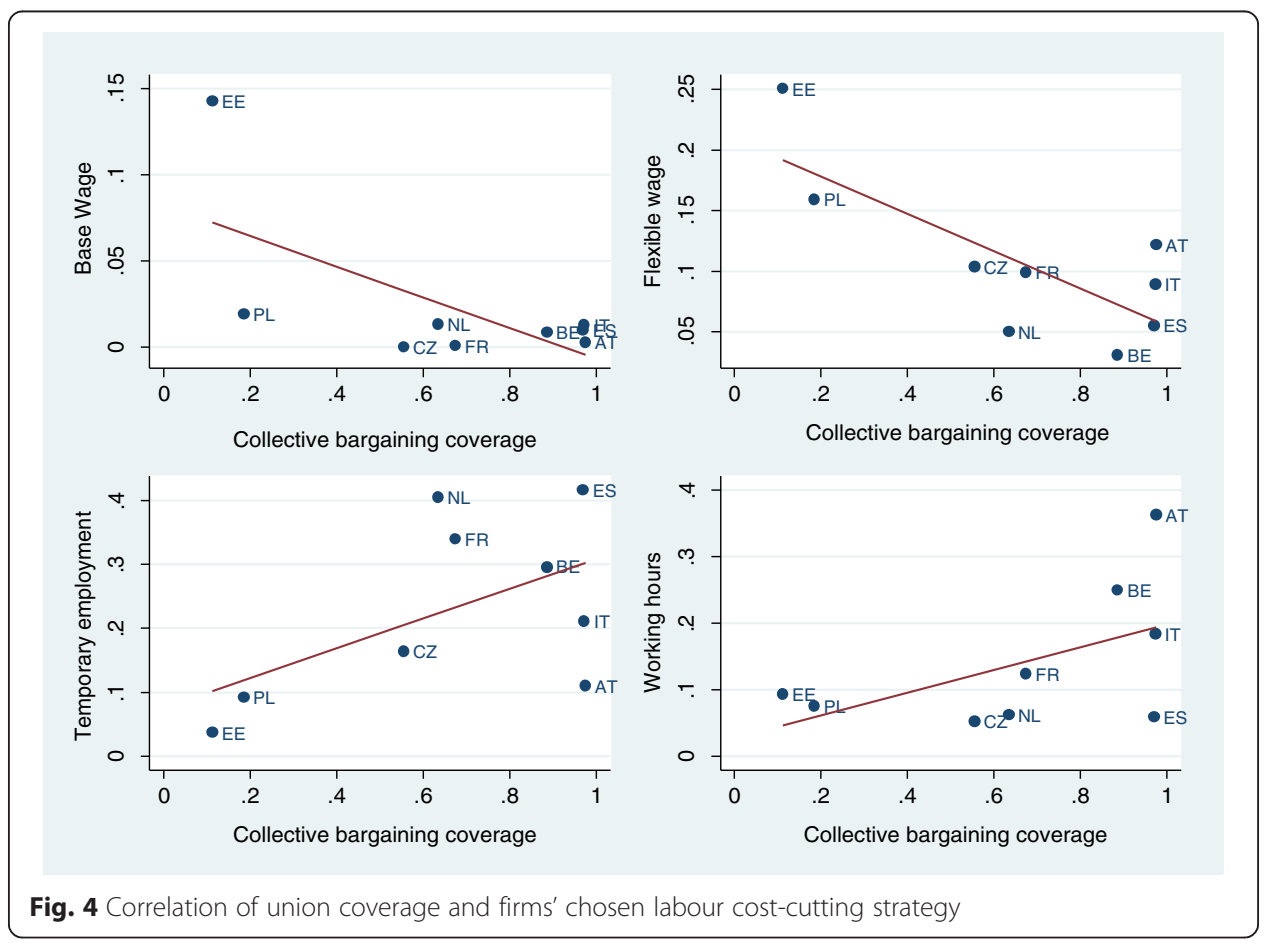


Table 10 Incidence of wage cuts and freezes by country and sector, 2007 and 2009 (percentages)

\begin{tabular}{|c|c|c|c|c|c|}
\hline & \multicolumn{3}{|c|}{ Firms that cut or froze wages } & \multicolumn{2}{|c|}{ Employees who received wage cuts or freezes } \\
\hline & 2007 & 2009 (past) & 2009 (expected) & 2007 & 2009 (past) \\
\hline \multicolumn{6}{|c|}{ Wage cuts: countries } \\
\hline Austria & 1.5 & 1.7 & 1.5 & 0.1 & 1.2 \\
\hline Belgium & 2.9 & 1.0 & 1.8 & 0.2 & 0.3 \\
\hline Czech Republic & 9.3 & 8.9 & 3.2 & 1.1 & 3.7 \\
\hline Estonia & 3.7 & 44.1 & 38.6 & 0.1 & 30.4 \\
\hline France & 2.5 & 1.9 & 4.7 & 0.9 & 1.2 \\
\hline Italy & 0.7 & 2.0 & 4.3 & 0.1 & 1.1 \\
\hline Netherlands & 1.6 & 2.6 & 3.8 & 0.8 & 1.2 \\
\hline Poland & 5.7 & 4.2 & 1.6 & 3.8 & 2.6 \\
\hline Spain & 0.1 & 2.6 & 0.5 & 0.0 & 1.4 \\
\hline Total & 2.6 & 3.2 & 3.1 & 1.0 & 1.8 \\
\hline Euro area & 1.3 & 2.1 & 3.3 & 0.2 & 1.1 \\
\hline Non-euro area & 6.4 & 6.5 & 2.7 & 3.1 & 3.7 \\
\hline \multicolumn{6}{|c|}{ Wage cuts: sectors } \\
\hline Manufacturing & 3.1 & 3.9 & 2.9 & 1.7 & 2.4 \\
\hline Trade & 1.3 & 2.8 & 2.3 & 0.6 & 1.8 \\
\hline Market Services & 2.8 & 2.4 & 4.2 & 0.5 & 1.1 \\
\hline \multicolumn{6}{|c|}{ Wage freezes: countries } \\
\hline Austria & 9.3 & 1.8 & 8.4 & 5.7 & 1.1 \\
\hline Belgium & 15.9 & 23.7 & 4.4 & 2.4 & 14.6 \\
\hline Czech Republic & 31.4 & 54.6 & 11.7 & 12.0 & 49.1 \\
\hline Estonia & 21.3 & 61.5 & 64.6 & 9.6 & 56.9 \\
\hline France & 7.7 & 86.0 & 83.8 & 5.3 & 82.5 \\
\hline Italy & 3.8 & 31.7 & 62.8 & 1.3 & 30.9 \\
\hline Netherlands & 25.8 & 15.2 & 8.7 & 15.9 & 12.6 \\
\hline Poland & 9.7 & 18.0 & 8.1 & 7.8 & 16.6 \\
\hline Spain & 1.5 & 26.7 & 3.7 & 0.8 & 22.2 \\
\hline Total & 9.5 & 34.5 & 34.5 & 5.2 & 31.9 \\
\hline Euro area & 7.6 & 37.1 & 43.1 & 3.9 & 34.4 \\
\hline Non-euro area & 14.8 & 27.4 & 10.3 & 8.8 & 25.0 \\
\hline \multicolumn{6}{|c|}{ Wage freezes: sectors } \\
\hline Manufacturing & 8.2 & 35.5 & 39.0 & 4.3 & 33.1 \\
\hline Trade & 7.0 & 26.4 & 26.2 & 3.0 & 23.3 \\
\hline Market Services & 12.2 & 42.0 & 39.4 & 7.0 & 39.4 \\
\hline
\end{tabular}

Source: WDN surveys. Note: The table presents percentages of firms and of employees; figures are employment-weighted and rescaled excluding "do not know" answers

\subsection{Estimating the probability of alternative cost-cutting strategies}

We conclude our analysis with an empirical exercise to explore in greater depth the firm-level and institutional features associated with the firms' choice of "most important" cost-cutting channel in reaction to demand and credit shocks. More specifically, we estimate a probit model for each of the cost reduction strategies described in subsection 6.1. 
The model predicts the probability that a firm will adopt a specific strategy-where the dependent variable is a 0-1 dummy-given a set of covariates that control for the firm's characteristics, workforce composition, institutional arrangements governing its wage setting, and other aspects of the economic environment.

The purpose of the exercise is to describe the responses of the firms' managers in different subsets of the population, not to estimate underlying parameters. Hence, we follow Hall and Krueger (2012) in the presentation of the results by using the predicted probabilities from the probit estimations.

As already stated in Section 2, the firms' characteristics used as covariates are derived from the first wave of the survey and hence do not refer to their conditions during the 2009 recession but to the their conditions in 2007. The variables used as covariates in the regression are the following:

- A set of indicators for the sector of economic activity (three categories: manufacturing, services, and trade)

- A set of indicators for the firm's size by number of employees (four categories: 5-19, 20-49, 50-199, and > =200)

- A set of indicators for the country where the firm operates (nine countries)

- A set of indicators for the nature and intensity of the shock faced by the firm (three categories: weak demand shock, strong demand and weak credit shock, and strong demand and credit shocks)

- The shares of white-collar, high-skilled, and permanent employees on total employment (continuous variables ranging from 0 to 1 )

- The share of flexible pay component (the fraction of bonuses on total pay, a continuous variable ranging from 0 to 1 )

- The fraction of the firm's employees covered by a collective wage agreement (a continuous variable ranging from 0 to 1 )

- An indicator for the presence of collective wage bargaining at the firm level

- An indicator for time-dependent wage setting at the firm level

- An indicator for firms that adjust wages more frequently than yearly

- The share of labour costs in total costs (a continuous variable ranging from 0 to 1 )

- An indicator for the intensity of competitive pressures faced by the firm

The variables concerning workforce composition, the share of labour costs on total costs, and collective bargaining coverage derive from the firms' quantitative answers to questions asking them explicitly to provide such figures. The other indicators are instead computed on the basis of qualitative information. The indicator for the presence of firm-level collective wage agreements is, rather straightforwardly, a dummy variable equal to 1 if collective bargaining occurs within the firm. We then define as time-dependent wage setters those companies that, when asked whether they typically implement wage changes at predetermined times of the year, answered positively (and indicated when, though this last piece of information is not used here). The indicator for frequent wage adjustment is computed on the basis of the answers related to the frequency of wage changes (independent of reasons) and is a dummy variable equal to 1 if the firm reported changing its wages more often than yearly. Finally, firms facing strong competitive pressures are those that reported being "likely" or "very likely" to decrease their own prices if their main competitors did the same. 
Table 11 summarises the means of the main covariates included in the analysis, both overall and by cost-cutting strategy (we exclude the "cutting base wages" strategy because, being the primary option for so few firms, it is of little relevance to this empirical exercise).

To capture possible nonlinearities, we map the continuous variables which are shares from 0 to 1 into three discrete classes based on their distribution: "low" if the share is between the 1st and 33rd percentiles; "medium" if it is between the 33rd and 66th percentiles; and "high" if it is above the 66th percentile. The distribution of the share of permanent employees is highly skewed: above the 40th percentile, all firms reported that their entire workforces had open-ended contracts. Hence, in this case we just construct an indicator taking the value of 1 if more than $95 \%$ of the firm's employees are permanent.

We present results in terms of the estimated probability of a "yes" answer from different types of firms, along with standard errors of the probability and of its difference with respect to the baseline. We concentrate on the estimated probabilities that are of direct relevance in light of the theoretical aspects discussed in Section 3. We proceed sequentially, with each table representing a cost-cutting strategy.

Our baseline case is a Czech firm operating in the business service sector; of small size (5-19 employees); facing weak demand and credit shocks; setting wages without a firm-level, collectively bargained contract and without a particular time pattern at less than yearly frequency; a firm whose workforce has low shares of temporary, whitecollar, and high-skilled workers; facing weak competitive pressures; having a low share of wages in total costs; and having a low incidence of bonuses. Before discussing the estimated probabilities, it should be emphasised that we found few nonlinearities in the estimated effects; hence, the tables below focus only on some of the extreme cases (those classified in the "high" class of the distribution).

The estimated probability of reducing the flexible wage component in response to the global crisis in reported in Table 12. Not surprisingly, firms with a higher fraction of bonuses on total pay in 2007 were more likely to use this margin of adjustment during the 2009 crisis: the estimated probability of cutting flexible pay as the main adjustment strategy is $21.3 \%$ for a high-bonus firm, compared with $13.7 \%$ in the baseline. Another aspect of the pay structure is also significant: firms that typically adjust wages more frequently were less likely to use flexible wage components to adjust their labour costs. In this case, the estimated probability of cutting flexible pay as the main adjustment strategy is $8.6 \%$, significantly below the baseline. However, another indicator of a rigid wage structure-a time-dependent wage-setting scheme-does not seem to significantly alter the probability of using this adjustment strategy.

Across industries, firms operating in manufacturing and in retail and wholesale trade were less likely to cut flexible wage components than firms in the business services that are included in the baseline. The estimated probabilities in manufacturing and trade are 8 and $8.3 \%$, respectively; in both cases, differences from the baseline are statistically significant. Note that this result holds over and above differences in the incidence of bonuses across sectors because we are holding the share of bonuses constant in this exercise (i.e., the estimated probabilities for the different sectors are relative to a baseline firm with a low share of bonuses). This result has two possible interpretations: either service sector firms were more likely to use the flexibility in bonuses intensively as a 
Table 11 Main covariates, by cost-cutting strategy (averages)

\begin{tabular}{|c|c|c|c|c|c|c|}
\hline Covariate & $\begin{array}{l}\text { Flexible } \\
\text { wages }\end{array}$ & $\begin{array}{l}\text { Permanent } \\
\text { employment }\end{array}$ & $\begin{array}{l}\text { Temporary } \\
\text { employment }\end{array}$ & $\begin{array}{l}\text { Hours } \\
\text { worked }\end{array}$ & $\begin{array}{l}\text { Nonlabour } \\
\text { costs }\end{array}$ & Total \\
\hline Manufacturing & 0.41 & 0.51 & 0.52 & 0.54 & 0.38 & 0.46 \\
\hline Services & 0.40 & 0.27 & 0.30 & 0.32 & 0.38 & 0.33 \\
\hline Trade & 0.19 & 0.22 & 0.19 & 0.15 & 0.25 & 0.21 \\
\hline Size: 5-19 & 0.15 & 0.14 & 0.07 & 0.07 & 0.18 & 0.13 \\
\hline Size: 20-49 & 0.24 & 0.23 & 0.16 & 0.27 & 0.26 & 0.23 \\
\hline Size: 50-199 & 0.21 & 0.21 & 0.20 & 0.20 & 0.19 & 0.20 \\
\hline Size: $>=200$ & 0.40 & 0.42 & 0.56 & 0.46 & 0.37 & 0.44 \\
\hline Austria & 0.05 & 0.03 & 0.02 & 0.11 & 0.03 & 0.04 \\
\hline Belgium & 0.01 & 0.03 & 0.03 & 0.05 & 0.02 & 0.03 \\
\hline Czech Republic & 0.05 & 0.08 & 0.03 & 0.02 & 0.06 & 0.05 \\
\hline Estonia & 0.03 & 0.01 & 0.00 & 0.01 & 0.01 & 0.01 \\
\hline France & 0.17 & 0.17 & 0.23 & 0.15 & 0.13 & 0.17 \\
\hline Italy & 0.34 & 0.36 & 0.32 & 0.50 & 0.37 & 0.37 \\
\hline Netherlands & 0.05 & 0.04 & 0.15 & 0.04 & 0.10 & 0.09 \\
\hline Poland & 0.26 & 0.16 & 0.06 & 0.09 & 0.23 & 0.16 \\
\hline Spain & 0.05 & 0.12 & 0.15 & 0.04 & 0.06 & 0.09 \\
\hline Weak demand shock & 0.55 & 0.45 & 0.50 & 0.50 & 0.72 & 0.57 \\
\hline Strong demand + weak credit shock & 0.36 & 0.31 & 0.36 & 0.36 & 0.20 & 0.30 \\
\hline Strong demand + strong credit shock & 0.09 & 0.25 & 0.13 & 0.15 & 0.08 & 0.13 \\
\hline Share of white-collar workers & 0.47 & 0.39 & 0.36 & 0.35 & 0.45 & 0.41 \\
\hline Share of high-skilled workers & 0.55 & 0.40 & 0.39 & 0.44 & 0.41 & 0.42 \\
\hline Share of permanent workers & 0.91 & 0.90 & 0.89 & 0.93 & 0.89 & 0.90 \\
\hline Flexible pay component & 0.10 & 0.10 & 0.08 & 0.07 & 0.11 & 0.09 \\
\hline Coverage of collective agreement & 0.62 & 0.73 & 0.80 & 0.85 & 0.67 & 0.73 \\
\hline Firm-level collective agreement & 0.36 & 0.38 & 0.45 & 0.47 & 0.32 & 0.39 \\
\hline Time-dependent wage change & 0.46 & 0.47 & 0.57 & 0.50 & 0.47 & 0.50 \\
\hline Frequent wage adjustment & 0.09 & 0.08 & 0.13 & 0.12 & 0.09 & 0.10 \\
\hline Labour cost share & 0.35 & 0.33 & 0.34 & 0.35 & 0.32 & 0.33 \\
\hline Strong competitive pressures & 0.65 & 0.58 & 0.58 & 0.49 & 0.57 & 0.57 \\
\hline
\end{tabular}

Source: WDN surveys. Note: The table presents employment-weighted averages

consequence of the crisis, or they have other forms of flexible pay that give additional leeway at the time of cutting wages, such as stock options and flexible fringe benefits.

The estimated effects of workers' characteristics are also in line with expectations: firms whose employees include a high percentage of white-collar workers were more likely to cut flexible wages (the difference from the baseline is 5.6 percentage points). Receiving a strong demand shock increases somewhat the probability, but the difference from the baseline is relatively small (3 percentage points); the fact that the shock is strong also on the credit side does not exert a significant impact ( -0.4 percentage points). Neither the type of wage contract nor the extent of product market competition affects the use of reductions of flexible pay.

We move next to the analysis of another cost-cutting option: employment adjustment (Table 13). The first two columns refer to layoffs of permanent employees, and columns 
Table 12 Probability of adjusting flexible wages

\begin{tabular}{|c|c|c|}
\hline & $\begin{array}{l}\text { Probability } \\
\text { (\% and standard errors) }\end{array}$ & $\begin{array}{l}\text { Difference from baseline } \\
\text { (\% points and standard errors) }\end{array}$ \\
\hline \multirow[t]{2}{*}{ Baseline } & 13.7 & \\
\hline & (5.6) & \\
\hline \multirow[t]{2}{*}{ Manufacturing } & 8.0 & -5.8 \\
\hline & $(3.9)$ & $(2.6)$ \\
\hline \multirow[t]{2}{*}{ Trade } & 8.3 & -5.4 \\
\hline & $(4.1)$ & $(2.8)$ \\
\hline \multirow[t]{2}{*}{ Large firm } & 12.9 & -0.9 \\
\hline & $(5.1)$ & (3.4) \\
\hline \multirow[t]{2}{*}{ Strong demand + weak credit shock } & 16.7 & 3.0 \\
\hline & $(6.4)$ & $(2.2)$ \\
\hline \multirow[t]{2}{*}{ Strong demand + strong credit shock } & 13.4 & -0.4 \\
\hline & $(5.4)$ & $(2.2)$ \\
\hline \multirow[t]{2}{*}{ Time-dependent wages } & 14.3 & 0.5 \\
\hline & $(5.8)$ & $(2.1)$ \\
\hline \multirow[t]{2}{*}{ Frequent wage adjustment } & 8.6 & -5.1 \\
\hline & $(4.4)$ & $(2.6)$ \\
\hline \multirow[t]{2}{*}{ Strong competitive pressures } & 14.4 & 0.7 \\
\hline & $(5.7)$ & $(1.9)$ \\
\hline \multirow[t]{2}{*}{ Firm-level collective agreement } & 12.8 & -0.9 \\
\hline & $(5.5)$ & $(2.2)$ \\
\hline \multirow[t]{2}{*}{ White-collar workers: high (\%) } & 19.3 & 5.6 \\
\hline & $(7.4)$ & (3.3) \\
\hline \multirow[t]{2}{*}{ High-skilled workers: high (\%) } & 17.2 & 3.4 \\
\hline & $(6.7)$ & $(3.0)$ \\
\hline \multirow[t]{2}{*}{ Temporary workers: high (\%) } & 11.2 & -2.6 \\
\hline & $(4.9)$ & $(2.1)$ \\
\hline \multirow[t]{2}{*}{ Labour cost share: high (\%) } & 14.0 & 0.2 \\
\hline & $(5.6)$ & $(2.2)$ \\
\hline \multirow[t]{2}{*}{ Flexible pay component: high (\%) } & 21.3 & 7.5 \\
\hline & $(7.2)$ & $(3.2)$ \\
\hline
\end{tabular}

Source: WDN surveys. Note: The table shows predicted probability from probit regression. Standard errors are shown in parentheses. The baseline case is a Czech firm operating in the business service sector; of small size (5-19 employees); facing weak demand and credit shocks; setting wages without a firm-level, collectively bargained contract and without a particular time pattern at less than yearly frequency; a firm having a workforce with low shares of temporary, whitecollar, and high-skilled workers; facing weak competitive pressures; and having a low share of wages in total costs and a low incidence of bonuses

3 and 4 to those of temporary workers. Consistently with the descriptive evidence provided above, relative to the other strategies the size of the shock is of fundamental importance to the firms' decision to cut the number of permanent workers: suffering a strong demand or credit shock almost doubles the probability that firms dismiss employees with open-ended contracts-differences from the baseline are highly significant in both cases. In contrast with the results on the adjustment through wages, neither workforce composition nor sector of operation has a significant effect.

In Section 3, we argued that stronger product market competition is likely to increase the elasticity of labour demand, hence making employment more responsive to shocks. 
Our results only partially confirm this; indeed, firms facing fiercer competition were more likely to cut permanent employees, although differences from the baseline are small (2.7 percentage points) and only marginally significant (standard error 1.5$)$. Also in line with theoretical predictions, firms with a relatively high share of labour costs were more likely to cut employment during the crisis: the estimated probability is $16.1 \%$, compared with $9.9 \%$ in the baseline.

Layoffs of temporary employees were, not surprisingly, more likely to occur in those firms employing a high share of temporary workers in 2007, as suggested by the positive difference from the baseline ( 3.2 percentage points), presented in column 4. Perhaps more interestingly, it is within larger firms that much of the adjustment occurred through fixed-term contracts: the likelihood of cutting temporary employment is more than double that of the baseline (16.1\% versus $7.6 \%)$ in firms with 200 employees or more. In this case, neither product market competition nor the share of labour costs in total cost seems to affect the likelihood of cutting temporary employment. Of similar interest is the negative impact of bonuses: in firms with a high share of bonuses, the probability of cutting temporary employment is almost 2 percentage points lower than the baseline, suggesting some degree of complementarity between flexible forms of payment and flexible forms of employment.

This complementarity is weakly confirmed by the results on the reduction of hours (first two columns of Table 14): the baseline probability of cutting hours worked is $4.6 \%$, compared with $3.1 \%$ among firms with a high share of bonuses in total pay. The difference, though, is not statistically significant.

As regards the adjustment by reducing nonlabour costs, the probit estimation confirms the raw differences in the means obtained in the descriptive analysis, suggesting that nonwage costs are likely to be the immediate reaction to a negative shock if the shock is small (last two columns of Table 14). The probability weakens as the size of the shock increases: the baseline estimate (66.8\%) drops by more than 20 percentage points if the firm is hit by a strong demand shock and by almost 10 percentage points if it is hit by both strong demand and credit shocks. Interestingly, nonlabour costs were also more commonly reduced during the recession by firms with more flexible wages, as captured by the frequent-wage-adjustment indicator (more often than once a year): the estimated difference is large (6.6 percentage points) and statistically significant. Larger firms were also less likely to select nonlabour costs as their main cost-cutting strategy, as suggested by the large difference ( -17.7 percentage points) from the baseline probability.

A last aspect is the role of unions and wage bargaining. Our indicator for the presence of a firm-level contract does not seem to alter significantly any of the adjustment mechanisms reviewed, which is in sharp contrast with the scatterplot diagrams measuring correlation between summary bargaining-power indicators and the countries' "most-chosen" cost-cutting options (Figs. 3 and 4, described early in this section). This finding depends on the fact that, by and large, differences in bargaining regimes within the sample countries are very limited, with some countries displaying ratios of collective bargaining coverage which are close to one. In this context, the role of wage bargaining in firms' choices is evident only when the between-country variation is exploited, a feature that our regressions do not allow because of the inclusion of country fixed effects. 
Table 13 Probability of cutting permanent and fixed-term employment

\begin{tabular}{|c|c|c|c|c|}
\hline & \multicolumn{2}{|c|}{ Permanent employees } & \multicolumn{2}{|c|}{ Fixed-term employees } \\
\hline & $\begin{array}{l}\text { Probability (\% and } \\
\text { standard errors) }\end{array}$ & $\begin{array}{l}\text { Difference from baseline } \\
\text { (\% points and standard } \\
\text { errors) }\end{array}$ & $\begin{array}{l}\text { Probability (\% and } \\
\text { standard errors) }\end{array}$ & $\begin{array}{l}\text { Difference from baseline } \\
\text { (\% points and standard } \\
\text { errors) }\end{array}$ \\
\hline \multirow[t]{2}{*}{ Baseline } & 9.9 & & 7.6 & \\
\hline & $(3.7)$ & & $(3.2)$ & \\
\hline \multirow[t]{2}{*}{ Manufacturing } & 12.4 & 2.5 & 8.5 & 0.9 \\
\hline & $(4.4)$ & (1.9) & $(3.4)$ & $(1.2)$ \\
\hline \multirow[t]{2}{*}{ Trade } & 13.3 & 3.4 & 7.1 & -0.4 \\
\hline & $(4.7)$ & $(2.4)$ & $(3.1)$ & $(1.4)$ \\
\hline \multirow[t]{2}{*}{ Large firm } & 11.0 & 1.1 & 16.1 & 8.6 \\
\hline & (3.9) & $(2.3)$ & (5.3) & (3.0) \\
\hline \multirow{2}{*}{$\begin{array}{l}\text { Strong demand }+ \\
\text { weak credit shock }\end{array}$} & 19.6 & 9.8 & 9.6 & 2.0 \\
\hline & (5.9) & $(2.7)$ & (3.9) & $(1.2)$ \\
\hline \multirow{2}{*}{$\begin{array}{l}\text { Strong demand }+ \\
\text { strong credit shock }\end{array}$} & 18.2 & 8.4 & 6.2 & -1.4 \\
\hline & $(5.7)$ & $(2.6)$ & $(2.8)$ & $(1.1)$ \\
\hline \multirow{2}{*}{$\begin{array}{l}\text { Time-dependent } \\
\text { wages }\end{array}$} & 7.9 & -2.0 & 9.7 & 2.1 \\
\hline & $(3.2)$ & $(1.3)$ & (3.8) & (1.3) \\
\hline \multirow{2}{*}{$\begin{array}{l}\text { Frequent wage } \\
\text { adjustment }\end{array}$} & 7.9 & -2.0 & 8.0 & 0.4 \\
\hline & (3.5) & $(1.7)$ & (3.5) & $(1.4)$ \\
\hline \multirow{2}{*}{$\begin{array}{l}\text { Strong competitive } \\
\text { pressures }\end{array}$} & 12.6 & 2.7 & 6.3 & -1.3 \\
\hline & $(4.4)$ & $(1.5)$ & $(2.7)$ & $(1.0)$ \\
\hline \multirow{2}{*}{$\begin{array}{l}\text { Firm-level } \\
\text { collective } \\
\text { agreement }\end{array}$} & 10.3 & 0.5 & 7.7 & 0.1 \\
\hline & $(4.0)$ & (1.6) & $(3.2)$ & (1.1) \\
\hline \multirow{2}{*}{$\begin{array}{l}\text { White-collar } \\
\text { workers: high (\%) }\end{array}$} & 11.3 & 1.5 & 4.6 & -2.9 \\
\hline & $(4.3)$ & (1.9) & $(2.3)$ & (1.4) \\
\hline \multirow{2}{*}{$\begin{array}{l}\text { High-skilled } \\
\text { workers: high (\%) }\end{array}$} & 10.7 & 0.8 & 6.6 & -1.0 \\
\hline & $(4.1)$ & (1.8) & (3.0) & $(1.2)$ \\
\hline \multirow{2}{*}{$\begin{array}{l}\text { Temporary } \\
\text { workers: high (\%) }\end{array}$} & 9.3 & -0.6 & 10.8 & 3.2 \\
\hline & (3.6) & (1.4) & $(4.1)$ & (1.5) \\
\hline \multirow{2}{*}{$\begin{array}{l}\text { Labour cost share: } \\
\text { high (\%) }\end{array}$} & 16.1 & 6.2 & 6.7 & -0.9 \\
\hline & (5.1) & $(2.3)$ & (2.9) & (1.1) \\
\hline \multirow{2}{*}{$\begin{array}{l}\text { Flexible pay } \\
\text { component: high } \\
(\%)\end{array}$} & 13.3 & 3.5 & 5.7 & -1.9 \\
\hline & $(4.5)$ & (2.0) & $(2.5)$ & (1.3) \\
\hline
\end{tabular}

Source: WDN surveys. Note: The table shows predicted probability from probit regressions. Standard errors are shown within parentheses. The baseline case is a Czech firm operating in the business service sector; of small size (5-19 employees); facing weak demand and credit shocks; setting wages without a firm-level, collectively bargained contract and without a particular time pattern at less than yearly frequency; a firm having a workforce with low shares of temporary, white-collar, and high-skilled workers; facing weak competitive pressures; and having a low share of wages in total costs and a low incidence of bonuses

\section{Conclusions}

We exploited a unique firm-level survey to study the responses of European firms to the sharp demand and credit reductions triggered by the global economic crisis of 2009. Most of the firms interviewed adopted at least one adjustment strategy to cope with the crisis; even those that fared relatively better, facing only weak reductions in demand, engaged in some reduction of costs, margins, or prices. Naturally, the share of 
Table 14 Probability of adjusting hours worked and nonlabour costs

\begin{tabular}{|c|c|c|c|c|}
\hline & \multicolumn{2}{|l|}{ Hours worked } & \multicolumn{2}{|l|}{ Nonlabour costs } \\
\hline & $\begin{array}{l}\text { Probability (\% and } \\
\text { standard errors) }\end{array}$ & $\begin{array}{l}\text { Difference from baseline } \\
\text { (\% points and standard } \\
\text { errors) }\end{array}$ & $\begin{array}{l}\text { Probability (\% and } \\
\text { standard errors) }\end{array}$ & $\begin{array}{l}\text { Difference from baseline } \\
\text { (\% points and standard } \\
\text { errors) }\end{array}$ \\
\hline \multirow[t]{2}{*}{ Baseline } & 4.6 & & 66.8 & \\
\hline & $(2.8)$ & & $(7.2)$ & \\
\hline \multirow[t]{2}{*}{ Manufacturing } & 5.7 & 1.0 & 62.6 & -4.1 \\
\hline & (3.3) & $(1.2)$ & (7.3) & (3.0) \\
\hline \multirow[t]{2}{*}{ Trade } & 3.1 & -1.6 & 69.0 & 2.2 \\
\hline & $(2.1)$ & (1.3) & $(7.0)$ & (3.3) \\
\hline \multirow[t]{2}{*}{ Large firm } & 5.8 & 1.2 & 49.1 & -17.6 \\
\hline & (3.2) & (1.6) & (7.9) & $(4.2)$ \\
\hline \multirow{2}{*}{$\begin{array}{l}\text { Strong demand }+ \\
\text { weak credit shock }\end{array}$} & 5.1 & 0.5 & 46.3 & -20.4 \\
\hline & (3.0) & $(0.8)$ & $(8.0)$ & $(2.6)$ \\
\hline \multirow{2}{*}{$\begin{array}{l}\text { Strong demand + } \\
\text { strong credit shock }\end{array}$} & 5.6 & 1.0 & 57.3 & -9.5 \\
\hline & (3.2) & $(1.0)$ & (7.9) & (3.0) \\
\hline \multirow{2}{*}{$\begin{array}{l}\text { Time-dependent } \\
\text { wages }\end{array}$} & 5.3 & 0.7 & 64.5 & -2.2 \\
\hline & $(3.2)$ & $(1.0)$ & $(7.5)$ & $(2.6)$ \\
\hline \multirow{2}{*}{$\begin{array}{l}\text { Frequent wage } \\
\text { adjustment }\end{array}$} & 4.1 & -0.6 & 73.4 & 6.6 \\
\hline & $(2.7)$ & (1.1) & (7.1) & (3.0) \\
\hline \multirow{2}{*}{$\begin{array}{l}\text { Strong competitive } \\
\text { pressures }\end{array}$} & 3.8 & -0.8 & 67.2 & 0.4 \\
\hline & $(2.4)$ & $(0.8)$ & $(7.2)$ & $(2.3)$ \\
\hline \multirow{2}{*}{$\begin{array}{l}\text { Firm-level } \\
\text { collective } \\
\text { agreement }\end{array}$} & 5.3 & 0.7 & 67.4 & 0.7 \\
\hline & (3.2) & (1.0) & (7.3) & $(2.9)$ \\
\hline \multirow{2}{*}{$\begin{array}{l}\text { White-collar } \\
\text { workers: high (\%) }\end{array}$} & 3.7 & -0.9 & 72.6 & 5.8 \\
\hline & $(2.5)$ & $(1.0)$ & $(7.0)$ & $(2.9)$ \\
\hline \multirow{2}{*}{$\begin{array}{l}\text { High-skilled } \\
\text { workers: high (\%) }\end{array}$} & 2.9 & -1.7 & 67.2 & 0.4 \\
\hline & $(2.0)$ & $(1.2)$ & $(7.5)$ & $(3.2)$ \\
\hline \multirow{2}{*}{$\begin{array}{l}\text { Temporary } \\
\text { employees: high } \\
\text { (\%) }\end{array}$} & 4.3 & -0.4 & 65.1 & -1.7 \\
\hline & $(2.7)$ & (0.8) & (7.3) & $(2.7)$ \\
\hline \multirow{2}{*}{$\begin{array}{l}\text { Labour cost share: } \\
\text { high (\%) }\end{array}$} & 4.2 & -0.5 & 61.6 & -5.2 \\
\hline & $(2.5)$ & $(1.0)$ & (7.4) & $(2.9)$ \\
\hline \multirow{2}{*}{$\begin{array}{l}\text { Flexible pay } \\
\text { component: high } \\
\text { (\%) }\end{array}$} & 3.1 & -1.6 & 64.3 & -2.4 \\
\hline & (2.0) & $(1.2)$ & (7.3) & (3.0) \\
\hline
\end{tabular}

Source: WDN surveys. Note: The table shows the predicted probability from probit regressions. Standard errors are shown within parentheses. The baseline case is a Czech firm operating in the business service sector; of small size (5-19 employees); facing weak demand and credit shocks; setting wages without a firm-level, collectively bargained contract and without a particular time pattern at less than yearly frequency; a firm having a workforce with low shares of temporary, white-collar, and high-skilled workers; facing weak competitive pressures; and having a low share of wages in total costs and a low incidence of bonuses

firms responding to the crisis increases with the intensity of the shock: when a strong demand reduction was coupled with an inability to access credit, $94 \%$ of the firms interviewed engaged in cost-cutting strategies. Adjusting either margins or output was the second-place option, chosen by approximately two-thirds of the companies.

As for the various cost reduction strategies that firms used, the one most commonly preferred was reduction of nonlabour costs. Although the survey did not investigate 
the nature of such costs, it seems plausible that they relate to ancillary activities and to the margins of input providers.

Firms which adjusted labour costs did so primarily by laying off temporary employees and reducing hours worked. Dismissal of permanent employees was instead relatively uncommon, confirming the dual nature of European labour markets.

Our findings sanction the firms' strong resistance to base wage cuts: the firms in our sample countries almost never implemented such reductions except in Estonia. There, almost $45 \%$ of the firms reduced nominal wages in response to the crisis, plausibly because of the downturn's exceptional magnitude relative to the other countries and because of the ample institutional flexibility in Estonian wage-setting practices.

Firms elsewhere reduced wages through a combination of base wage freezes and cuts in flexible pay components: overall, slightly more than $30 \%$ of employees experienced wage freezes in summer 2009, whereas wage freezes had affected, on average, less than $5 \%$ of employees in the five years from 2003 through 2007. Thus, despite the presence of extremely slow growth and even negative inflation rates, downward nominal wage rigidity remained a binding constraint for firms' wage bill adjustments.

\section{Endnotes}

${ }^{1}$ A similar survey was also conducted in Germany, but the main questions used in this paper are not comparable (Radowski and Bonin 2009).

${ }^{2}$ The harmonised questionnaires of both surveys contained core sets of questions which were asked in all countries. Some of the national questionnaires were further adapted to account for specific country characteristics and differences in institutional framework. As a result, some countries opted for shorter versions of surveys, while others extended them in several dimensions.

${ }^{3}$ For each firm or observation, these weights indicate the number of employees a given observation represents in the population. Those numbers are calculated as the sum of all employees in the population within a sampling category (by country, sector, firm size, and sometimes region, depending on the sampling strata) divided by the number of observations in that category. They were produced by the WDN staff and made available in the harmonised dataset.

${ }^{4}$ The correlation also hinges on Poland, which is the country that hardly experienced any GDP contraction.

${ }^{5}$ However, firms may undertake costly activities with long run potential, like research, product development, or training of employees. These activities are often cut when firms are cash constrained, and this should not be interpreted as the firms not minimising costs. We also acknowledge that economic conditions change once the shock occurs. In particular, if the shock is shared across firms and deteriorates other markets (e.g., the markets for intermediate goods and labour), opportunities may well emerge to trade down wages and input prices. Unfortunately, the broad level of the sector classification in our data does not allow us to distinguish between purely idiosyncratic shocks and aggregate or sectoral ones.

${ }^{6}$ Other potential combinations were chosen by less than $5 \%$ of the firms and are not shown in Table 7. 
${ }^{7}$ Akerlof et al. (1996) reported results from phone interviews with 409 individuals in the Washington, DC area who had not changed jobs during the previous 12 months; among them, only seven reported salary cuts. Fehr and Goette (2005) analysed yearly wage changes from company files for two Swiss firms in the service industry during low-inflation years. In the larger firm, only $1.7 \%$ of the observations constituted wage cuts, while the percentage in the medium-size firm was even lower, at $0.4 \%$.

${ }^{8}$ This evidence contrasts with some perceptions in the media during that period that certain large companies lowered wages to protect jobs. On April 9, 2009, the Wall Street Journal published an article titled "Salary cuts: ugly, but it could be worse" that repeated news of recent moves towards wage cuts by important firms, including Hewlett-Packard, A.H. Belo Corp., and the Atlanta Symphony Orchestra, among others. "Organizations in dire straits may have no choice but to slash salaries across the board," the article stated. Similar pieces in the Financial Times and leading economic magazines were published during the same period.

${ }^{9}$ Estonia's less-stringent EPL is not reflected in the OECD EPL index that we use in this study, which relies on EPL in 2008.

\section{Additional file}

Additional file 1: The 2009 survey questionnaire. (DOC $53 \mathrm{~kb}$ )

\section{Competing interests}

The IZA Journal of Labor Policy is committed to the IZA Guiding Principles of Research Integrity. The authors declare that they have observed these principles.

\section{Acknowledgements}

The work was conducted within the framework of the Wage Dynamics Network coordinated by the European Central Bank. We would like to thank all the participants of the meetings of the Wage Dynamics Network for their helpful comments and work on compiling the country data. We thank László Halpern, Andrea Weber and seminar participants at the Banque de France and the IX CEPR/ECB Labor Market Workshop. The opinions expressed in this paper are solely those of the authors and do not necessarily reflect the views of their institutions. Finally, we would like to thank the anonymous referee of this manuscript for the thoughtful review.

Responsible editor: Juan F Jimeno

\section{Author details}

${ }^{1}$ Banca d'Italia, Rome, Italy. ${ }^{2}$ European Central Bank, Frankfurt, Germany. ${ }^{3}$ Inter-American Development Bank,

Washington, USA. ${ }^{4}$ ZZA, Bonn, Germany. ${ }^{5}$ Bank of Estonia, Tallin, Estonia.

Received: 8 May 2015 Accepted: 6 August 2015

Published online: 29 December 2015

\section{References}

Akerlof GA, Dickens WT, Perry GL (1996) "The Macroeconomics of Low Inflation." Brookings Papers Economic Activity 1996 27(1):1-76

Babecký J, Caju PD, Kosma T, Lawless M, Messina J, Rõõm T (2010) Downward nominal and real wage rigidity: survey evidence from European firms. Scand J Econ 112(4):643-920

Bertola G (1999) Microeconomic perspectives on aggregate labour markets. In: Ashenfelter O, Card D (eds) Handbook of Labour Economics, Vol. 3C. North-Holland, Amsterdam, pp 2985-3028

Bertola G, Dabusinskas A, Hoeberichts M, Izquierdo M, Kwapil C, Montornès J, Radowski D (2012) Price, wage and employment response to shocks: evidence from the WDN survey. Labour Econ 19(5):783-791

Caggese A, Cuñat V (2008) Financing constraints and fixed term employment contracts. Econo J Royal Econom Soc 118(533):2013-2046

Dabušinskas A, Rõõm T (2011) "Survey Evidence on Wage and Price Setting in Estonia." Working Papers of Eesti Pank No 6/2011.

Fehr E, Goette L (2005) Robustness and real consequences of nominal wage rigidity. J Monet Econ 52(4):779-804

Green E, Porter RH (1984) Noncooperative collusion under imperfect price information. Econometrica 52(1):87-100

Guiso L, Pistaferri L, Schivardi F (2005) Insurance within the firm". J Polit Econ 113(5):1054-1087

Hall RE, Krueger AB (2012) Evidence on the incidence of wage posting, wage bargaining and on-the-Job search. Am Econom J 4(4):56-67

Holden S (2004) The costs of price stability—downward nominal wage rigidity in Europe. Economica 71(282):183-208 
Holden S, Wulfsberg F (2008) "Downward Nominal Wage Rigidity in the OECD.". BE J Macroeconomics 8(1 Advances):Article 15

Keynes JM (1936) The general theory of interest, employment and money. Macmillan Cambridge University Press, London

McDonald I, Solow R (1981) Wage bargaining and employment. Am Econ Rev 71(5):896-908

Phelps ES (1968) Money-wage dynamics and labor market equilibrium. J Polit Econ 76(4):678-711

Radowski D, Bonin H (2009) Downward nominal wage rigidity in services: direct evidence from a firm survey". Econ Lett 106(3):227-229

Rotemberg J, Saloner G (1986) A supergame-theoretic model of price wars during booms. Am Econ Rev 76(3):390-407

Taylor JB (1980) Aggregate dynamics and staggered contracts. J Polit Econ 88(1):1-23

Submit your manuscript to a SpringerOpen ${ }^{\circ}$ journal and benefit from:

- Convenient online submission

- Rigorous peer review

- Immediate publication on acceptance

- Open access: articles freely available online

- High visibility within the field

Retaining the copyright to your article

Submit your next manuscript at $\boldsymbol{~ s p r i n g e r o p e n . c o m ~}$ 